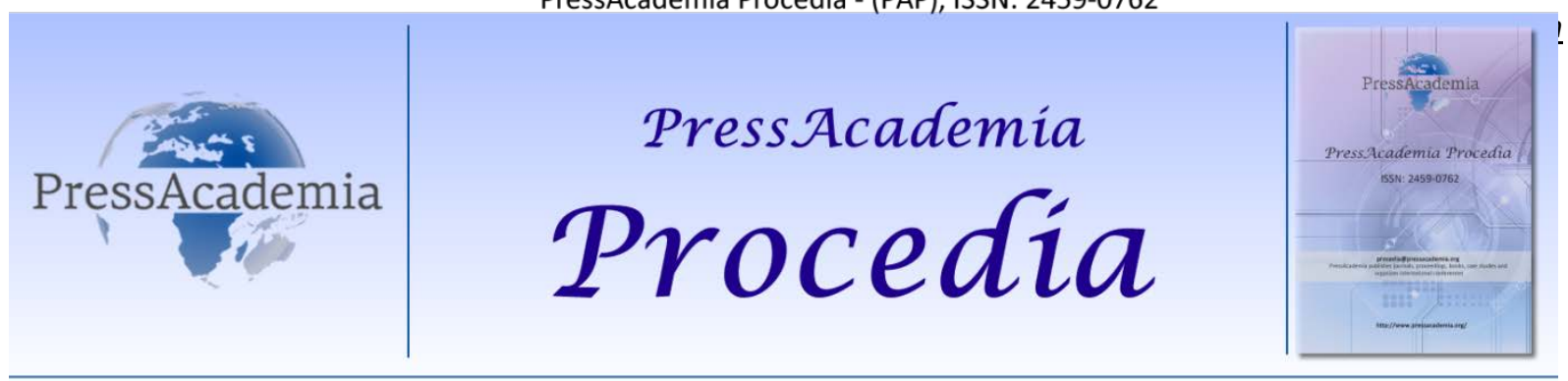

Global Business Research Congress (GBRC), May 26-27, 2016, Istanbul, Turkey.

\title{
PSYCHOLOGICAL CAPITAL RESEARCH FOR RELATIONS WITH CAREER ADAPTABILITY
}

\section{DOI: 10.17261/Pressacademia.2016118663}

\section{Nuray Mercan}

Dumlupınar Üniversitesi, nuraymercan26@gmail.com

\begin{abstract}
Special decision, especially in terms of career college years are a critical period in which they make important decisions regarding the future careers of young people s. During this period, the decisions taken regarding the future careers of young people vocational, psychological and physical well-being affects the overall quality of life due to social acceptance. The increasingly complex labor market and fear their entry into professional life are concerned that university students and reduce their good future prospects. The most important concern of our country is to settle on a suitable work students approaching graduation. In the rapidly changing environment of the 21 st century, new career models of labor flexibility should emphasize adaptability and lifelong learning. The aim of this study was to investigate the positive psychological capital in the context of career adaptability of University Students. Our research on Dumlupınar University of Economics and Administrative Sciences Faculty of education in business administration from randomly selected sample of 374 students were administered the questionnaire.
\end{abstract}

Keywords: Psychological capital, career adaptability

JEL Codes: M10,M11,M18

\section{PSIKOLOJIK SERMAYENIN KARIYER UYUM YETENEĞi iLE ILIŞKISINE YÖNELIK BíR ARAŞTIRMA}

\section{ÖZET}

Kariyer, bireyin kimliğini, toplumsal durumunu, statüsünü ve yaşam tarzını oluşturmasından dolayı büyük öneme sahiptir. İnsan, çalışma hayatına atıldığı ilk günden itibaren ihtiyaçlarını karşılamak, beklenti ve arzularını tatmin etmek, geleceğe yönelik planlar yaparak yükselmek, ilerlemek ve başarılı olmak istemektedir. Meslek hayatına atılmanın getirdiği korku ve gittikçe karmaşıklaşan iş piyasaları üniversite öğrencilerini endişelendirmekte ve iyi bir gelecek umutlarını azaltmaktadır. Ülkemizde mezuniyet yaklaştıkça üniversite öğrencilerinin en önemli endişesi uygun bir işe yerleşebilmektir. 21. yüzyılda hızla değişen çevrede, yeni kariyer modelleri işgücü esnekliğini, uyum yeteneklerini ve yaşam boyu öğrenmeyi vurgulamalıdır. Bu çalışmanın amacı, Üniversite Öğrencilerinin pozitif psikolojik sermayelerinin kariyer uyum yetenekleri bağlamında incelenmesidir. Araştırmamız, Dumlupınar Üniversitesi İktisadi ve İdari Bilimler Fakültesinde eğitim alan işletme bölümü öğrencileri arasından tesadüfi olarak seçilen 374 örneklem üzerinde anket yöntemiyle uygulanmıştır. Yapılan araştırmada psikolojik sermaye ile kariyer uyum yeteneği özellikleri arasında regresyon analizinde pozitif anlamlı ilişkiler bulunmuştur.

Anahtar Kelimeler: Psikolojik sermaye, Kariyer uyum yeteneği JEL Kodları: M10,M11,M18 


\section{GíRiş}

Günümüz çalışma yaşamında performans artışı için ölçülebilen, geliştirilebilen ve etkin olarak yönlendirilebilen insan kaynağı potansiyelinin ve psikolojik durumunun incelenmesine ilişkin uygulamalar olarak adlandırılan "psikolojik sermaye" kavramının çalışanların tutum ve davranışları üzerinde ne derece etkili olduğu yapılan çalışmalarla ortaya çıkarılmıştır. İş performansı, iş tatmini, örgütsel bağlılık ve örgütsel vatandaşlık davranışı gibi önemli örgütsel davranış değişkenleri üzerinde bulunan önemli etkileri, pozitif psikolojik sermaye konusunu anlaşılmaya ve üzerinde çalışılmaya değer bulunmuştur.

Luthans (2002a) kavramı "günümüz iş ortamlarının performansını artırmak için insan kaynaklarının güçlü yönleri ve psikolojik kapasitesi üzerindeki çalışma ve uygulamalar" şeklinde tanımlamaktadır. Gerçekte iş hayatında pozitif ve negatif durumlar/olaylar/deneyimler, birbirleriyle iç içe geçmiş şekilde bulunmaktadırlar. Bu nedenle pozitifliğe çok fazla odaklanıp, negatif durumları gözardı etmek doğru değildir. Pozitif örgütsel davranış pozitif ve negatif faktörleri en uygun şekilde harmanlayarak, insan kaynağını geliştirmeyi ve bu sayede örgütsel performansı artırmayı amaçlamaktadır. Dolayısıyla pozitif örgütsel davranış alanındaki araştırma ve uygulamalar da, bu denge mantığı çerçevesinde yürütülmektedir (Polatcı, 2011: 25). Kariyer uyumu, bireyin bir mesleki role hazırlanırken ya da o role girmek üzereyken karşılaşması muhtemel gelişimsel görevleriyle başa çıkmaya hazır olmasının yanı sıra mesleğin kendisinden ya da çalışma şartlarından kaynaklanan beklenmeyen değişimlerle başa çıkmaya hazır olma gücünü açıklar (Ömeroğlu,2014).

Bu araştırmada ilk olarak literatür taraması arkasından uygulama ve bulgular gösterilecektir.

\section{LITERATÜR TARAMASI}

\subsection{Pozitif Psikolojik Sermaye}

Pozitif psikoloji de, bireylerin problemlerinden ziyade, iyi taraflarına odaklanmaktadır. Bu doğrultuda, bireyleri daha olumlu yapan özelliklerin tanımlanması açısından, pozitif psikoloji bilimi, örgütlere katkılar sağlamaktadır (Brandt, Gomes ve Boyanova, 2011: 269). Pozitif psikolojinin örgüt yaşamındaki yansıması olarak nitelendirilebilecek olan pozitif örgütsel davranış kavramı, pozitif psikolojik sermayenin ortaya atılmasını sağlamıştır (Güler, 2009: 142-143). Birçok teori ve araştırma, psikolojik sermayeyi gelişmekte olan bir konu olması, hem bireysel hem de örgütsel düzeyde pozitif sonuçlarla olan ilişkisi sebebiyle desteklemektedir (Luthans ve diğ., 2010: 41). Psikolojik sermaye genel itibariyle, kim olduğumuzdan öte, en iyi olma ve ileride ne olacağımız ile ilgili bir kavramdır (Luthans ve diğ., 2010: 42). Geleneksel ekonomik sermaye kavramına benzer şekilde psikolojik sermaye kavramı, performansın geri dönüşümü ve rekabet avantajı için yapılan yatırımdır (Luthans, Vogelgesang ve Lester, 2006: 26) Pozitif psikoloji akımının örgüt ortamına olan yansıması ise, iki alt akım ile kendini göstermektedir. Bunlardan biri Pozitif Örgütsel Davranıştır. Pozitif Örgütsel Davranış, " günümüz çalışma hayatının gelişimi için ölçülebilir, geliştirilebilir ve etkin bir şekilde yönetilebilir pozitif yönelimli olan insan kaynaklarına ilişkin güçlü yönler ve psikolojik kapasiteler üzerinde yapılan çalışma ve uygulama" olarak ifade edilmektedir.Diğer akım ise Pozitif Örgütsel Düşünce Okulu olup, kriz ve olumsuz koşullarda örgütün yaşamını devam ettirmesi için pozitif özellikleri vurgulamaktadır ( Güler,2009).

Günümüzde yaşamında her alanda karşılaşılan değişim örgütlere rekabet üstünlüğü sağlayan sermaye türlerini de etkilemiştir. Geleneksel olarak kabul edilen finansal, fiziksel ve teknolojik sermaye türleri sürdürülebilir rekabet için gerekli olsalar da, artık yeterli olmamaktadırlar. Rekabet edilebilirlikte insan faktörünü ön plana çıkaran beşeri, sosyal ve pozitif psikolojik sermaye gibi yeni sermaye türlerinin önemi gittikçe artmaktadır (Luthans\&Youssef, 2004). Pozitif örgütsel davranış akımı doğrultusunda şekillenen psikolojik sermaye;

- Zorlu işleri başarmak için gerekli çabayı gösterebileceğine güvenme (özyeterlilik), • Şimdi ve gelecekte başarılı olmaya dair olumlu beklenti (iyimserlik), • Hedeflere ulaşmak için azim gösterme (umut), • Zorluklar ve sıkıntılar karşısında ayakta kalabilme ve herşeye rağmen başarıya ulaşma (dayanıklılık) özellikleri ile açıklanabilen bireyin gelişimine dair olumlu psikolojik durumdur. 


\subsection{Kariyer Uyumu Ve Kariyer Uyum Yeteneği}

Kariyer uyumu kavramı Super (1980)' ın kariyer olgunluğu kavramının üstüne inşa edilen bir kavramdır. Ergenlik dönemindeki ilgi ve yeteneklerin keşfi ve kariyer araştırmaları aşamasının devamında yetişkinliğe geçişte ve yetişkinlikte kariyer uyumundan söz edilmektedir. Super ve Knasel (1981), kariyer uyumunu, iş ve iş alanlarına değişikliklerle baş etmeye hazır bulunmak olarak açıklamışlardır (Akt. Hall ve Chandler, 2005). Ardından Savickas (1997) kariyer uyumu kavramını geliştirmiş ve kişinin kariyer geçiş sürecinde karşılaştığı beklenen ya da beklenmeyen durumlardaki değişikliklerle baş edebilmesi ve yeni rollere uyum sağlayabilmesi olarak açıklamıştır. Kişinin bu uyum sürecini atlatmasında öz farkındalık, mesleki farkındalık, destek (aile, çevre gibi), kontrol, iş yaşam dengesi ve kendine duyduğu güven gibi faktörler önem taşımaktadır. Diğer taraftan söz konusu durumdaki bu kişilerin yaşamlarında yeni durumlarla baş etmede sahip oldukları iyimserlik eğilimleri ile uyum süreçleri arasındaki ilişki dikkat çekmektedir. Araştırmada Türk kültürüne ve Türkiye sistemine uygun üniversite eğitiminden sonra çalışma yaşamına geçiş aşamasındaki bireylerin kariyer geleceklerine ilişkin kariyer uyumlarını ve iyimserliklerini ölçmeye yarayan bir ölçme aracı geliştirilmiş; aracın geçerlik ve güvenirlik çalışmaları yapılmıştır. KUiö’ nün yapı geçerliği açımlayıcı ve doğrulayıcı faktör analizleri kullanılarak incelenmiştir (Zorver ve Owen,2014).

Super'ın kuramı üzerinde çalışan ve onun açıklamalarını genişleterek Kariyer Yapılandırma Kuramını (Career Construction Theory) ortaya atan Savickas (1997, 2002), artık Super'ın kuramının merkez öğelerinden biri olan "kariyer olgunluğu ya da mesleki olgunluk (career maturity)" kavramının yerine "kariyer uyumu (career adaptibility)" kavramının koyulabileceğini ifade etmektedir. Çünkü ona göre Super'ın bu kavramı ergen kariyer gelişimine odaklanmakta ve yetişkinlerdeki kariyer gelişimi sürecini yeterince iyi değerlendirmemektedir. Savickas'a göre kariyer uyumu kavramı daha geniş bir bakış açısına sahiptir; bireyin ortaya çıkan yeni durumlara ya da değişimlere zorlanmadan uyum sağlayabilme çabasını açıklamaktadır. Savickas'a (1997) göre kariyer uyumluluğu kişinin gelecekteki kariyer durumu ile ilgili tahminlerde bulunabilmesi, karşılaşacağı engellerle etkin bir biçimde başa çıkacak becerilerini geliştirmesidir. Bireyler bu engelleri ne kadar doğru öngörebilir ve bu engellere çözümler üretebilirlerse yeni kariyerlerine o derece kolay uyum sağlayabilirler. Günümüzde yeni ve beklenmedik durumlara uyum sağlayabilmek daha önemli hale gelmiştir. Bu doğrultuda düşünüldüğünde "kariyer uyumu"; bireyin bir mesleki role hazırlanırken ya da o role girmek üzereyken karşılaşması muhtemel gelişimsel görevleriyle başa çıkmaya hazır olmasının yanı sıra mesleğin kendisinden ya da çalışma şartlarından

kaynaklanan beklenmeyen değişimlerle başa çıkmaya hazır olma gücünü açıklar (Savickas, 2002). Savickas (1997), mesleki olgunluktan kariyer uyumuna bu geçişin Super'ın yaşam boyu kariyer gelişimi ve yaşam alanı kuramlarını, çocukların, ergenlerin ve yetişkinlerin kariyer gelişimi ile ilgili bilgileri tek bir yapıda açıkladığını ifade etmiştir. Kariyer uyumuna doğru bu dönüşüm, bireylerin tüm yaşlarda, tüm yaşam rollerinde meydana gelebilecek değişimlerle başa çıkmaya hazır olmasını amaçlamaktadır. Kariyer uyumu, ister ergen olsun ister yetişkin, planlı tutumları, benliğin ve çevrenin keşfini ve bilgiyle donanmış bir şekilde karar almayı içermektedir. Kariyer uyumu özellikle günümüzün teknolojisinde ve ekonomisinde meydana gelen hızlı değişimler göz önüne alındığında doğru bir kavram gibi görünmektedir.

\section{VERI VE YÖNTEM}

Psikolojik sermaye kavramı, kendi yeterliliklerinin farkında olan, geleceğe dönük olumlu beklentiler içerisinde çalışan, kendinden emin, zorluklarından üstesinden gelen çalışanlara, yani psikolojik sermaye düzeyleri yüksek çalışanlara ihtiyaç vardır. 26 maddeden oluşan pozitif psikolojik sermaye ölçeği, ikinci bölümde ise 10 maddeden oluşan kişisel bilgiler kısmı yer almaktadır. Birinci bölüm için 5'li likert dereceleme yapılmıştır. Buna göre; “1: Tamamen Katılıyorum”, "2: Çoğunlukla Katılıyorum”, “3: Kararsızım”, "4: Az Katılıyorum” ve "5:Hiç Katılmıyorum” şeklinde tanımlanmıştır. Araştırmada kullanılacak ölçekler Savickas ve Profeli'nin (2012) çalışmasında "uluslararası kariyer uyum yetenekleri ölçeği" olarak adlandırılan, Türkçe yapı geçerlilik çalışması Kanten (2012) tarafından yapılan ve 13 ülkeye mensup 18 araştırmacının ortak çalışması sonucunda oluşturulan ölçekten yararlanılacaktır. Bu ölçekte (Savickas ve Profelie: 2012); kaygı, kontrol, merak, ve güven boyutları olmak üzere toplam 24 ifade bulunmaktadır. 


\section{VERILERIN ANALIZI VE BULGULAR}

Bu kısımda araştırmanın örneklemi, modeli, hipotezleri, anketin güvenilirliği ve elde edilen verilerin analizi ile hipotez testleri ve elde edilen sonuçların yorumları yer almaktadır.

Tablo 1: Demografik Değişkenlere iliş̧kin Bulgular

\begin{tabular}{|c|c|c|c|c|c|}
\hline \multicolumn{3}{|c|}{ Medeni Durum } & \multicolumn{3}{|c|}{ Cinsiyet } \\
\hline & FREKANS & YÜZDE & & FREKANS & YÜZDE \\
\hline 1.Öğretim & 278 & 74,3 & Kadın & 253 & 67,6 \\
\hline 2.Öğretim & 96 & 25,7 & Erkek & 121 & 32,4 \\
\hline Total & 374 & 100,0 & Total & 374 & 100,0 \\
\hline \multicolumn{3}{|c|}{ Yaş } & \multicolumn{3}{|c|}{ Gelir Düzeyi } \\
\hline $18-20$ & 3 & 8 & 1000 altı & 82 & 21,9 \\
\hline $21-22$ & 143 & 38,2 & $1001-1500$ & 81 & 21,7 \\
\hline $23-25$ & 174 & 46,5 & $1501-2000$ & 84 & 22,5 \\
\hline $26-28$ & 46 & 12,3 & $2001-2500$ & 45 & 12,0 \\
\hline $28-32$ & 8 & 2,1 & 2500n ve üzeri & 82 & 21,9 \\
\hline Total & 374 & 100,0 & Total & 374 & 100,0 \\
\hline
\end{tabular}




\section{BULGULAR VE TARTIŞMA}

Şekil 1: Araştırmanın Modeli
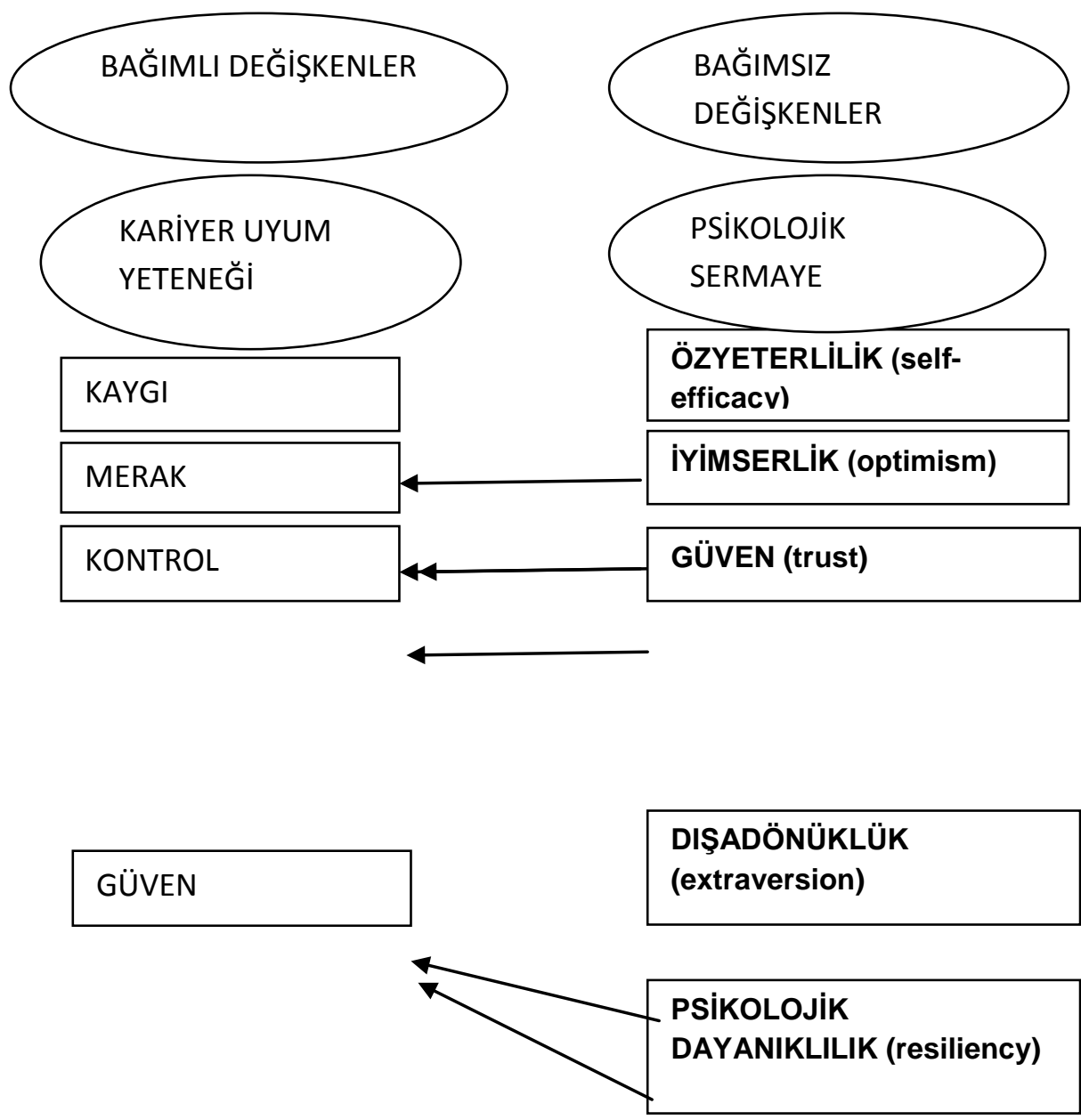

UMUT (hope)

Tablo 2: Güvenilirlik Analizi Sonuçları

\begin{tabular}{|c|c|c|c|}
\hline Boyut Adı & $\begin{array}{l}\text { Boyutların Cronbach } \\
\text { Alfa Katsayıları }\end{array}$ & $\begin{array}{l}\text { Ölçeklerin } \\
\text { Cronbach Alfa } \\
\text { Katsayıları }\end{array}$ & $\begin{array}{l}\text { Toplam Ölçek } \\
\text { Cronbach Alfa } \\
\text { Katsayıları }\end{array}$ \\
\hline & Kariyer uyum yeteneği & \multirow{6}{*}{,743 } & \multirow[b]{7}{*}{85,4} \\
\hline Kaygı & ,560 & & \\
\hline Kontrol & ,513 & & \\
\hline Güven & ,574 & & \\
\hline Merak & ,705 & & \\
\hline \multicolumn{2}{|c|}{ Pozitif psikolojik sermaye boyutları } & & \\
\hline Özyeterlilik (self-efficacy) & 663, & ,832 & \\
\hline
\end{tabular}




\begin{tabular}{|l|r|r|}
\hline İyimserlik (optimism) &, 809 \\
\hline Güven (trust) &, 723 \\
\hline Dışadönüklük (extraversion) & & \\
\hline Psikolojik dayanıklılık (resiliency) & & \\
\hline Umut (hope) & & \\
\hline
\end{tabular}

Uygulanan anketin güvenilirlik sonuçlarına baktığımızda her bir faktörün yeterli düzeyde güvenilirliğe sahip olduğu görülmektedir. Tablo 2'de görüldüğü gibi anketin genel güvenilirliği 0,832 olarak bulunmuştur.

Tablo 3: Korelasyon Analizi Sonuçları

\begin{tabular}{|c|c|c|c|c|c|c|c|c|c|c|}
\hline Değişkenler & 1 & 2 & 3 & 4 & 5 & 6 & 7 & 8 & 9 & $\begin{array}{l}1 \\
0\end{array}$ \\
\hline 1. Kaygı & 1 & & & & & & & & & \\
\hline 2.Kontrol & $\begin{array}{r}, 239{ }^{* *} \\
\text { ) }\end{array}$ & 1 & & & & & & & & \\
\hline 3.Güven & ,466 ${ }^{* *}$ & ,369(** & 1 & & & & & & & \\
\hline 4.Merak & $\begin{array}{r}, 266\left(^{* *}\right. \\
)\end{array}$ & $\begin{array}{r}, 413(* * \\
)\end{array}$ & $\begin{array}{r}, 493(* * \\
)\end{array}$ & 1 & & & & & & \\
\hline $\begin{array}{l}\text { 5.Özyeterlili } \\
\text { k }\end{array}$ & $\begin{array}{r}, 407\left(^{* *}\right. \\
)\end{array}$ & $\begin{array}{r}, 341\left(^{* *}\right. \\
)\end{array}$ & $\begin{array}{r}, 694(* * \\
)\end{array}$ & $\begin{array}{r}, 405\left(^{* *}\right. \\
)\end{array}$ & 1 & & & & & \\
\hline 6.İyimserlik & ,363(** & $\begin{array}{r}, 397(* * \\
\text { ) }\end{array}$ & ,502(** & $\begin{array}{r}, 345(* * \\
)\end{array}$ & ,569(** & 1 & & & & \\
\hline 7.Güven & $\begin{array}{r}, 497\left(^{* *}\right. \\
)\end{array}$ & $\begin{array}{r}, 314(* * \\
)\end{array}$ & ,621(** & $\begin{array}{r}, 360\left(^{* *}\right. \\
)\end{array}$ & $\begin{array}{r}, 577\left(^{* *}\right. \\
)\end{array}$ & $\begin{array}{r}, 491\left(^{* *}\right. \\
\text { ) }\end{array}$ & 1 & & & \\
\hline $\begin{array}{l}\text { 8.Dışa } \\
\text { dönüklük }\end{array}$ & ,465(** & ,337(** & ,649(** & ,449(** & ,636(** & ,500(** & ,661(** & 1 & & \\
\hline $\begin{array}{l}\text { 9.Psikolojik } \\
\text { Dayanıklılık }\end{array}$ & ,397(** &, $363(* *$ & ,709/** &, $477(* *$ & ,670(** & ,559(** & ,6561** & ,715(** & 1 & \\
\hline 10.Umut & $\begin{array}{r}, 454(* * \\
)\end{array}$ & $\begin{array}{r}, 347(* * \\
)\end{array}$ & ,651(** & $\begin{array}{r}, 410(* * \\
)\end{array}$ & ,649(** & $\begin{array}{r}, 496\left(^{* *}\right. \\
\text { ) }\end{array}$ & $\begin{array}{r}, 658(* * \\
)\end{array}$ & $\begin{array}{r}, 686\left(^{* *}\right. \\
)\end{array}$ & $\begin{array}{r}, 747\left(^{* *}\right. \\
)\end{array}$ & 1 \\
\hline
\end{tabular}

$* p<0,05, * * p<0,01$

Kültürler arası duyarlılık ile iletişim becerileri boyutları arasındaki ilişkiyi görmek maksadıyla korelasyon analizi yapılmıştır. Tablo 3’de görüldüğü gibi boyutlar arasında anlamlı ilişki vardır. 
Tablo 4: Kaygı ile Psikolojik Sermaye Boyutları Arasındaki Çoklu Regresyon Analizleri

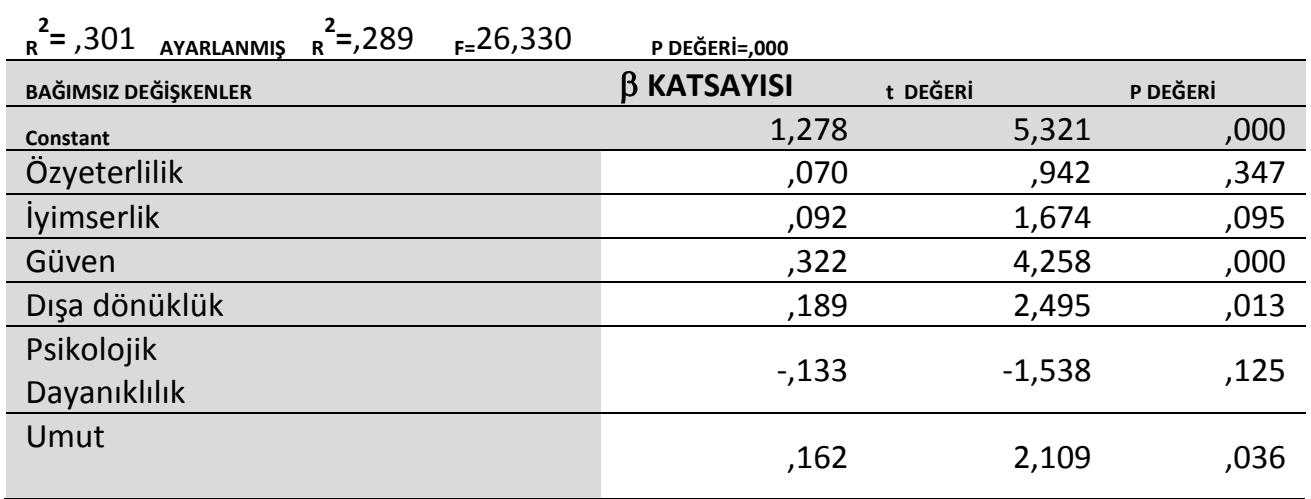

Yapılan çoklu regresyon analizinde öğrencilerin kariyer uyum yeteneği boyutlarından kaygı ile psikolojik sermaye boyutları olan güven, dışa dönüklük ve psikolojik dayanıklılık arasında pozitif bir ilişki olduğu $t$ sayısında görülmektedir.

Tablo 5: Kontrol ile Psikolojik Sermaye Boyutları Arasındaki Çoklu Regresyon Analizleri

\begin{tabular}{|c|c|c|c|}
\hline BAĞıMSIZ DEĞişKENLER & $\beta$ KATSAYISI & t DEĞERi & P DEĞERI \\
\hline Constant & 1,883 & 10,810 &, 000 \\
\hline Özyeterlilik & 034 & 629 & ,530 \\
\hline İyimserlik & ,164 & 4,122 & 000 \\
\hline Güven & ,019 & ,341 & ,734 \\
\hline Dışa dönüklük & ,042 & ,764 & ,446 \\
\hline $\begin{array}{l}\text { Psikolojik } \\
\text { Dayanıklılık }\end{array}$ & ,058 & 924 & ,356 \\
\hline Umut & ,059 & 1,060 & ,290 \\
\hline
\end{tabular}

Yapılan çoklu regresyon analizinde öğrencilerin kariyer uyum yeteneği boyutlarından kontrol ile psikolojik sermaye boyutları olan iyimserlik arasında pozitif bir ilişki olduğu t sayısında görülmektedir

Tablo 6: Güven Ille Psikolojik Sermaye Boyutları Arasındaki Çoklu Regresyon Analizleri

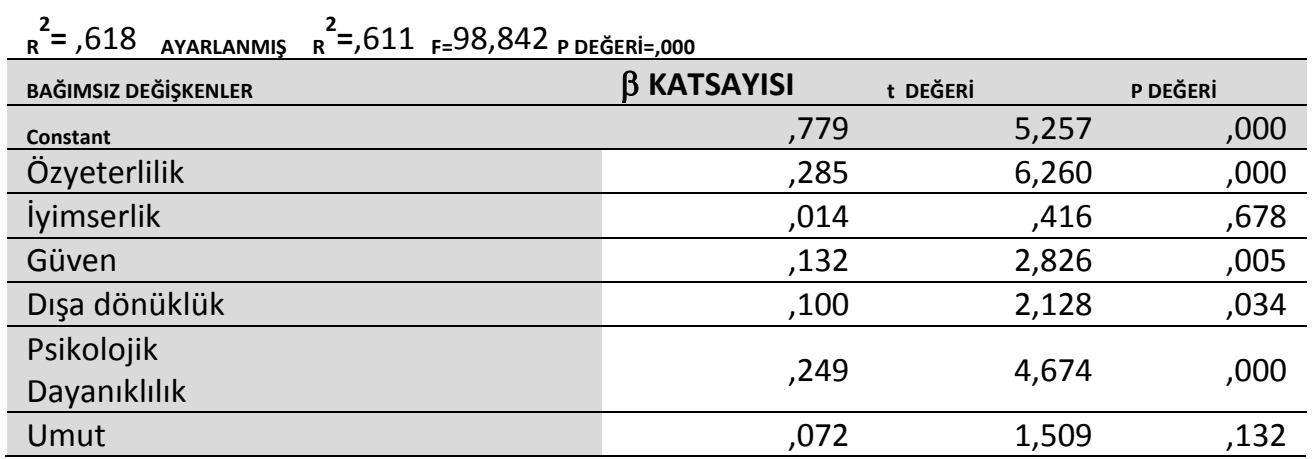


Yapılan çoklu regresyon analizinde öğrencilerin kariyer uyum yeteneği boyutlarından güven ile psikolojik sermaye boyutları olan Özyeterlilik, güven, dışa dönüklük ve psikolojik dayanıklılık arasında pozitif bir ilişki olduğu t sayısında görülmektedir.

Tablo 7: Merak i̇le Psikolojik Sermaye Boyutları Arasındaki Çoklu Regresyon Analizleri

\begin{tabular}{|c|c|c|c|}
\hline BAĞIMSIZ DEĞișKENLER & $\beta$ KATSAYISI & t DEĞERI & PDEĞERI \\
\hline Constant & 1,770 & 10,284 &, 000 \\
\hline Özyeterlilik & ,060 & 1,136 & ,257 \\
\hline İyimserlik & ,045 & 1,139 & ,255 \\
\hline Güven &,- 017 &,- 315 & ,753 \\
\hline Dışa dönüklük & 138 & 2,532 & ,012 \\
\hline $\begin{array}{l}\text { Psikolojik } \\
\text { Dayanıklılık }\end{array}$ & 195 & 3,148 & ,002 \\
\hline Umut & ,021 & , 389 & 697, \\
\hline
\end{tabular}

Yapılan çoklu regresyon analizinde öğrencilerin kariyer uyum yeteneği boyutlarından kaygı ile psikolojik sermaye boyutları olan dışa dönüklük ve psikolojik dayanıklılık arasında pozitif bir ilişki olduğu $t$ sayısında görülmektedir

\section{SONUÇ}

Kariyer konusunda bazı kararlar kişi tarafından, bazıları örgüt tarafından, bir kısmı da kişi ve örgüt tarafından birlikte alınmaktadır. Dolayısıyla belirtmek gerekir ki; kariyer sadece bireysel bir olgu değildir. Kişinin kariyeri, içinde bulunduğu okul ve örgüt tarafından da meydana getirilir, diğer bir deyişle okullar, kişilerin kariyerlerinin belirlenmesinde etkileyici rol üstlenmektedir. Kişisel amaçlar, örgüt amaçlarıyla aynı perspektifte yer aldığı sürece örgüt amaçlarını gerçekleştirmek bir zorunluluk olmaktan çıkıp, kişinin kendi hedefleri haline gelir. Kariyer olgusu bireylerin yaşamlarının büyük bölümüne hâkim olması açısından da oldukça önemlidir. Kişinin psikolojik ve sosyal bakımdan gelişimini yakından ilgilendirmekle birlikte kariyer, bireyin kendini tanımlaması ve kendi sınırlarının farkında olmasını sağlar. Bu durumda şöyle denilebilir ki, bireyin tatmin düzeyi kariyerinin ulaşabileceği noktaları gösterirken, başarı, sorumluluk alabilme sistematiğini de geliştirmektedir. Kariyer, kişinin yaşamında ilk olarak maddi ve somut katkılarda bulunur, insanların yaşamlarını ideal düzeyde gerçekleştirebilmeleri için kariyer basamaklarını daha hızlı tırmanmaları ve geldikleri noktada kalıcı olmaları gerekir. Yapılan çoklu regresyon analizinde öğrencilerin kariyer uyum yeteneği boyutlarından kaygı ile psikolojik sermaye boyutları olan güven, dışa dönüklük ve psikolojik dayanıklılık arasında pozitif bir ilişki olduğu saptanmıştır. Öğrencilerin kariyer uyum yeteneği boyutlarından kontrol ile psikolojik sermaye boyutları olan iyimserlik arasında pozitif bir ilişki olduğu diğer bir analizde meydana getirilmiştir. Regresyon analizinde öğrencilerin kariyer uyum yeteneği boyutlarından kaygı ile psikolojik sermaye boyutları olan dışa dönüklük ve psikolojik dayanıklılık arasında pozitif bir ilişki olduğu görülmektedir. Kariyer, bir kişinin tüm çalışma yaşamını kapsar. Bu açıdan bir kişinin kariyeri, okuldan ayrılışı ve örgütsel yaşama girişi ile başlayan, bağımsız bir şekilde deneyim kazanmasıyla ve sorumluluk yüklenmesiyle devam eden, örgütte yukarı, ya da yana doğru hareketini kapsayan ve işgücünden temelli ayrılma, bir diğer ifade ile emeklilikle son bulan bir süreçtir. 


\section{KAYNAKLAR}

Beğenirbaş, M., 2015, "Psikolojik sermayenin çalışanların duygu gösterimleri ve işe yabancılaşmalarına etkileri: sağlık sektöründe bir araştırma" Süleyman Demirel Üniversitesi Iktisadi Ve Idari Bilimler Fakültesi Dergisi , C.20, S.3, S.249-263.

Brandt, T., Gomes, J. F. S. ve Boyanova, D., 2011, "Personality and psychological capital as Indicators of future job success?", LTA, 3/11, 263-289.

Hall, D. T. \& Chandler, D. E. 2005, "Psychological success: when the career is a callingy". Journal Organizational Behavior, 26, 155-176.

Güler, B., K., 2009, “Çalışma yaşamında davranış”, Kocaeli:Umuttepe Yayıncılık.

Kanten, S., 2012, "kariyer uyum yetenekleri ölçeği: geçerlilik ve güvenilirlik çalışması" Süleyman Demirel Üniversitesi Sosyal Bilimler Enstitüsü DergisiYıl: 2012/2, Sayı:16 Journal of Süleyman Demirel University Institute of Social SciencesYear: 2012/2, Number:16.

Luthans, F., Avey, J. , Avolio, B. J. ve Peterson, S. , 2010, “The development and resulting performance Impact of positive psychological capital", Human Resource Development Quarterly , 21 (1), 41-67.

Luthans, Fred \& Youssef, C. M. 2004, "Human, social and now positive psychological capital management: Investing in people for competitive advantage", Organizational Dynamics. 33:2, 143-160.

Luthans, F., \&Vogelgesang, G. R. \& Lester, P. B. 2006, "Developing the psychological capital of resiliency", Human Resource Development Review, 5,1.

Luthans, F., 2002, "Positive organizational behavior: developing and managing psychological strengths", Academy of Management Executive. 16, 57-72.

Ömeroğlu, S., 2014, “Polis akademisi öğrencilerine yönelik kariyer uyumu programının etkililiğinin değerlendirilmesi” Ankara üniversitesi eğitim bilimleri enstitüsü eğitimde psikolojik hizmetler anabilim dalı rehberlik ve psikolojik danışmanlık programı , Yüksek lisans tezi Ankara ocak, 2014

Polatçı, S., 2014, "Psikolojik sermayenin görev ve bağlamsal performans üzerindeki etkileri: polis teşkilatında bir araştırma” Ege Akademik Bakış / Ege Academıc Revıew, Cilt: 14 , Sayı: 1, ss. 115-124.

Savickas, M. L. 2002, "Career construction: a developmental theory of vocational behavior". D. Brown and Associates içinde, Career Choice and Development (Fourth Edition) (s. 149-206). San Francisco: Jossey-Bass.

Savickas, M. L. 1997, “Career adaptability: an Integrative construct for life-span”, Life-Space Theory. The Career Development Quarterly, 45 , 247-259.

Savıckas, M.L. \& Porfelı, E.J. 2012, "The career adapt-abilities scale: Construction, reliability, and measurement equivalence across 13 countries", Journal of Vocational Behavior, 80, pp. 661-673, 2012.

Super, D. E. 1980, “A life-span, life-space approach to career development”. Journal of Vocational Behavior, 16, 282-298.

Zorver, C., E., \& Korkut Owen, F. 2014, “Kariyer uyumu ve iyimserliği ölçeği'nin geliştirilmesi”. International Journal of Human Sciences, 11(2), 314-331. doi: 10.14687/ijhs.v11i2.2911 